\title{
Oxidative stress biomarkers in Oreochromis niloticus as early warning signals in assessing pollution from acid mine drainage and diffuse sources of pollutants in a subtropical river
}

\author{
Z Jiri' ${ }^{12 *}$, A Tazvivinga ${ }^{2}$, R Greenfield' and JHJ van Vuren' \\ 'Department of Zoology, University of Johannesburg, Box 524 Auckland Park 2006, South Africa \\ 2 Department of Biological Sciences, Bindura University of Science Education, P Bag 1020, Bindura, Zimbabwe
}

\begin{abstract}
This study investigated the use of an exotic fish species Oreochromis niloticus as a bio-indicator organism in active biomonitoring of Yellow Jacket and Mazowe rivers, Zimbabwe, receiving acid mine drainage from Iron Duke Mine. The Yellow Jacket River flows through Iron Duke Pyrite Mine while the Mazowe River passes through the Mazowe factory and estate shop that receives runoff from intensive agricultural activities. Active biomonitoring (ABM) exposures were conducted for 6 weeks in effluent-contaminated sections of the rivers during high flow, from February to March 2013. A set of biomarkers of exposure and effect (glutathione S-transferase, catalase and metallothioneins) were selected and their responses determined in O. niloticus liver, gills and muscle. We hypothesized that the increase in activities of GST, CAT and MT in exposed fish, in comparison to control fish, can be used to assess river water quality using O. niloticus. Biomarker expression was measured after 4 and 6 weeks and compared against control fish kept under laboratory conditions without contaminants. Concentrations of zinc, cadmium, chromium, nickel, lead, copper, manganese, arsenic and iron were measured in flowing water, riverbed sediments and muscle tissue of actively biomonitored O. niloticus. Key water quality parameters, including dissolved oxygen and conductivity, clearly showed a pollution gradient from Iron Duke Mine. Expression of CAT and GST was highest in the liver, compared to gills and muscles, after 4 and 6 weeks of exposure, and their expression was lower $(p<0.05)$ in control fish. The expression of the enzymes was not significantly different after 6 weeks compared to 4 weeks. Increased enzyme expressions at Site 1, which is upstream from Iron Duke Mine, were comparable to enzyme expressions at Sites $3,4,5$ and 6 , which correlated with increased zinc concentrations in the exposed fish muscle tissue. The general order of metal concentrations was sediments $>$ water $>$ fish, except for zinc, which had the highest bioconcentration factors. Using the GST, CAT and MT we concluded that Mazowe and Yellow Jacket rivers are contaminated and that these oxidative stress biomarkers can successfully be used in assessing pollution from point sources such as acid mine drainage, as well as diffuse sources of pollutants such as commercial agriculture.
\end{abstract}

Keywords: acid mine drainage, active biomonitoring, biomarkers, fish, pollutants

\section{INTRODUCTION}

Acid mine drainage can degrade water quality (Nyamadzawo, 2007; Ravengai et al., 2005) and poses a threat to native aquatic life (William and Smith, 2000) through elevated acidity and the accumulation of metals through increased mobility and bioavailability of these metals.

Biomarkers are topical in ecotoxicology because they provide functional measures of receptor species and exposure to environmental stressors that can be better related to adverse effects of human activities (Adams et al., 2001). They can provide a functional measure of organism response when exposed to single and complex mixtures of chemical stressors that are bioavailable in the environment. Biomarkers can provide early warning of potential higherlevel effects that may not be obtainable through chemical analyses or other methods of investigation. The most compelling reason for using biomarkers is that they can give information on biological effects of pollutants rather than a mere quantification of their environmental levels (Wepener et al., 2005). Enzyme activities which include oxidative stress biomarkers and sub-cellular components are the most commonly used biomarkers. These have been shown to be

\footnotetext{
To whom all correspondence should be addressed.

e-mail: zviregei@gmail.com or zjiri@buse.ac.zw

Received 20 September 2016; accepted in revised form 10 April 2018
}

sensitive indicators demonstrating the penetration of a toxic substance into the organism and its distribution among tissues (Slatinska et al., 2008). Oxidative stress biomarkers are known biomarkers of metal exposure and effect. Glutathione S-transferase activity in fish, especially in areas polluted by metals, pesticides and other industrial contaminants, appears to be the most sensitive and widely used catalytic probe to observe and monitor pollution of aquatic ecosystems (Gadagbui and James, 2000).

The monitoring of aquatic systems to slow down biodiversity loss is in line with both the UN Convention on Biological Diversity (CBD) of 2002 and Goal Number 7 of the Millennium Development Goals (MDG), i.e. halving the proportion of people without access to safe drinking water by 2015 (Muisa et al., 2010). Iron Duke Mine (IDM) is one of the most studied mines causing acid mine drainage and affecting surface water in Zimbabwe. Studies, however, have concentrated on the chemical characterization of pollutants (William and Smith, 2000; Nyamadzawo, 2007; Ravengai et al., 2005; Chizvondo, 2007; Magadza and Masendu, 1986) and only a few have looked at the effects of acid mine drainage on benthic macroinvertebrates. However, there is no study that has employed active biomonitoring in the Mazowe and Yellow Jacket Rivers, which are important tributaries of the Zambezi River. Although a combination of active and passive biomonitoring is a potentially excellent tool to manage ambient water quality, this approach is not yet 
widely used for research purposes in Zimbabwean freshwater systems. Zimbabwe, as a signatory to the SADC Protocol on Shared Watercourses, is mandated to reduce and control the environmental degradation of the Zambezi River (SADC, 2000). The purpose of this study was to determine the level of water quality impairment by measuring a set of biomarkers in Oreochromis niloticus in parallel with metal contaminants in water and sediments to obtain comprehensive information regarding the environmental status of the investigated area. The set of biomarkers of exposure and effect (glutathione S-transferase, catalase and metallothioneins) were selected and their responses determined in O. niloticus liver, gills and muscle. We hypothesized that GST, CAT and MT can be used as biomarkers to assess river water quality using O. niloticus.

\section{MATERIALS AND METHODS}

Field sampling was approved by the Zimbabwe National Water Authority and ethical approval for this study was provided by the University of Johannesburg where the laboratory analyses were carried out (Faculty Of Science Ethics Committee Number $02 / 2013(3)$ ). The study area is located $17^{\circ} 28^{\prime} \mathrm{S}$ and $31^{\circ} 15^{\prime} \mathrm{E}$, about $50 \mathrm{~km}$ north of Harare on the highveld of Zimbabwe. The area receives an average rainfall of 800 to $1000 \mathrm{~mm} / \mathrm{a}$, which normally falls between the months of November and April. The study area experiences dry cold winters from May to July with average temperatures of $15^{\circ} \mathrm{C}$ and the summer season runs from November to April with average daily temperatures of $30^{\circ} \mathrm{C}$. The Yellow Jacket and Mazoe Rivers run through the Iron Mask Mountain Range, which stretches from the Iron Cap Mine area in the South to the Shamva area in the North-East, forming an actuate structure (Ravengai et al., 2005). The Yellow Jacket River cuts through the Iron Mask Range at Iron Duke Mine and flows north into the larger Mazowe River, which flows along the western edge of the range (Ravengai et al., 2005). The study area is covered by Miombo woodland with dominant tree species that include Brachystegia spiciformis, Brachystegia bohemii and Julbernadia globiflora, with some scattered within the woodland. Iron Duke Mine is one of the most studied mines causing AMD and affecting surface water in Zimbabwe, with identified sources being the underground tailings, waste rock dump, the processing plant and the evaporation ponds. The study was conducted during the rainy season as runoff and seepage from the evaporation ponds was observed to increase during this season. A set of biomarkers of exposure and effect (glutathione S-transferase, catalase and metallothioneins) were selected and their responses determined in O. niloticus liver, gills and muscle. Oxidative stress biomarkers were used in this study as they are known biomarkers of metal exposure and effect. We hypothesized that GST, CAT and MT can be used as biomarkers to assess river water quality using $O$. niloticus.

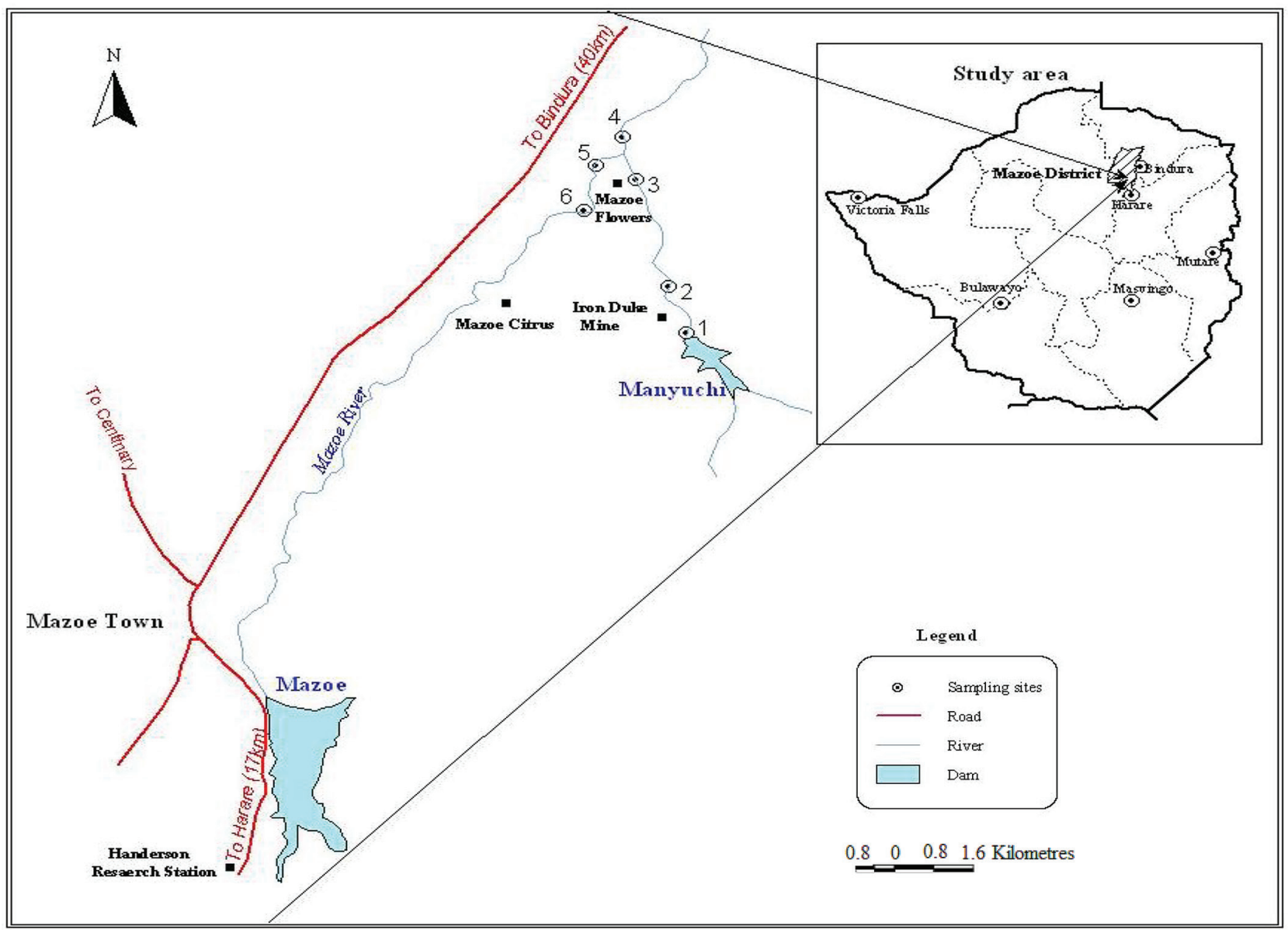

Figure 1

Map showing the study area within Glendale and the location of 6 sampling sites on the Yellow Jacket and Mazoe rivers, as well as Henderson Research Station 


\section{Study design}

The study was carried out during the high flow (wet rainy season) from February to March 2013. A total of 6 sites were selected: 3 sites along the Yellow Jacket River, 2 sites along the Mazoe River and 1 site after the confluence of the two rivers (Fig. 1). The sites were chosen according to accessibility and have been used in previous studies (Tazvivinga et al., 2012). The Nile Tilapia (Oreochromis niloticus), was used as the bioindicator organism because it is hardy, survives under extreme environmental conditions, grows more rapidly and to a larger size than any of the indigenous Zimbabwean tilapias and has become the main commercial fish in Zimbabwe (Mhlanga et al., 2006). Disease-free fish were obtained from Henderson Research Station Fisheries Section. Fish of the same age and average standard lengths of $6 \pm 1.3 \mathrm{~cm}$ and average weight of 80 $\pm 1.2 \mathrm{~g}$ were used. Fish were deployed in non-toxic polythene cages that were placed on the riverbed at selected sites along the two rivers and at a reference site above the Iron Duke Mine. Ten fish per cage were deployed in duplicate at selected sites for 6 weeks. Fish were sacrificed on site by severing the spinal cord and dissecting the gill, liver and muscle tissue.

\section{Water sampling}

Physicochemical parameters were measured in situ during deployment and sampling for biomarkers. Temperature $\left({ }^{\circ} \mathrm{C}\right)$ and conductivity $(\mu \mathrm{S} / \mathrm{cm})$ were measured in situ, using a YSI-30 Salinity-Conductivity-Temperature meter. A Fisher Sientific Acumen AP 60 portable $\mathrm{pH}$ meter was used for measuring $\mathrm{pH}$. Water samples were collected in $500 \mathrm{~mL}$ plastic bottles that had been washed with a phosphate-free detergent, rinsed in distilled water and left to stand overnight in $2 \%$ hydrochloric acid and rinsed again in distilled water. $50 \mathrm{~mL}$ of each water sample was filtered through a $0.45 \mu \mathrm{m}$ Whatman membrane filter and acidified to $\mathrm{pH}$ below 2 by adding $1.5 \mathrm{~mL}$ Suprapur $\mathrm{NHO} 3$ (65\%), to prevent metals from adsorbing to the containers. Filtering was done to remove suspended organic and inorganic solids that could react with dissolved ions and alter the chemistry of the water. The methods are described in detail in an earlier study (Tazvivinga et al., 2012).

\section{Sediment sampling}

Sediment samples were collected from each site using an acid-washed polyethene corer to a depth of $3 \mathrm{~cm}$. At each sampling site, 3 samples were collected within a distance of $15 \mathrm{~m}$ upstream and downstream from a central point in the emergent zone (Mlambo, 2010). The sediments were stored in sterilised polyethene bags and taken to the laboratory in sealed containers containing ice packs and stored at $-40^{\circ} \mathrm{C}$. Acid digestion to extract the metals from sediments was done by adding $9 \mathrm{~mL}$ hydrochloric acid (30\%) and $3 \mathrm{~mL}$ nitric acid $(65 \%)$ to $0.2 \mathrm{~g}$ of oven-dried sample and digesting at $200^{\circ} \mathrm{C}$ for $20 \mathrm{~min}$ in a Milestone microwave digestion system. The samples were kept at $200^{\circ} \mathrm{C}$ for an additional $20 \mathrm{~min}$ and left to cool for $10 \mathrm{~min}$ thereafter. The contents of the digestion vessels were decanted into $50 \mathrm{~mL}$ polypropylene volumetric flasks and made to volume using distilled water (MilliQ) (Gerber et al., 2015).

\section{Fish sampling}

Muscle tissue samples from Oreochromis niloticus exposed during active biomonitoring were oven-dried at $65^{\circ} \mathrm{C}$ for
$96 \mathrm{~h}$ and used for metal analysis to determine metal bioconcentration in the fish. Acid digestion to extract metals from O. niloticus muscle tissue was done by adding $10 \mathrm{~mL}$ of Suprapur $\mathrm{NHO}_{3}(65 \%)$ and $1 \mathrm{~mL}$ of $\mathrm{H}_{2} \mathrm{O}_{2}$ to $0.5 \mathrm{~g}$ of ovendried sample and digesting at $200^{\circ} \mathrm{C}$ for $25 \mathrm{~min}$ in a Milestone microwave digestion system. The samples were kept at $200^{\circ} \mathrm{C}$ for an additional $15 \mathrm{~min}$ and left to cool for $10 \mathrm{~min}$ thereafter. The contents of the digestion vessels were decanted into $50 \mathrm{~mL}$ polypropylene volumetric flasks and made to volume using distilled water (MilliQ).

\section{Biomarker assays}

O. niloticus were given 2 weeks to acclimatise before sampling for biomarker assays on the $4^{\text {th }}$ and $6^{\text {th }}$ week after deployment. Pooled fish samples from the two cages were used. The fish were sacrificed on site by severing the spinal cord and dissected for the liver, gills and muscle tissues. The samples were stored in Hendrickson stabilizing buffer at $-80^{\circ} \mathrm{C}$ until biomarker analysis at the University of Johannesburg Ecotoxicology Laboratory. Catalase activity was determined following the method of Cohen et al. (1970). GST activity was determined by the method of Habig et al. (1974) using 1-chloro-2,4-dinitrobenzene (CDNB) as substrate. MT was determined following the method of Viariengo et al. (1997). The enzyme activities were measured as specific activities expressed in units of activity per mg of protein. The Bradford method (Bradford, 1976) was used to determine protein concentration in the samples and involves the binding of Coomassie Brilliant Blue G250 to protein.

\section{Metal determination}

The following metals in water, sediments and fish were determined on the ICP-OES (Spectro Arcos FSH12): Fe, Cr, $\mathrm{Mn}, \mathrm{Co}, \mathrm{Ni}, \mathrm{Cu}, \mathrm{Zn}, \mathrm{Cd}, \mathrm{Pb}$ and $\mathrm{Al}$. Those metals that were below detection on the ICP-OES, as well as As, were analysed on the ICP-MS (X-series II). Concentrations were expressed as $\mu \mathrm{g} / \mathrm{g}$ of fish tissue/sediment and $\mu \mathrm{g} / \mathrm{L}$ water. To correct for interference from high levels of dissolved solids in the different matrices, indium was used as an internal standard. Quality control of metal measurements was verified by including process blanks and certified reference material (CRMs) for sediments, namely SL-1 (IAEA). The CRM was digested and analysed in triplicate. The percentage recoveries of the certified values were acceptable and ranged between 80 and $110 \%$

\section{TABLE 1}

Total metal $(\mu \mathrm{g} / \mathrm{kg})$ extracted from SL-1(IAEA) certified reference material and the percentage recovery of the experimental procedure

\begin{tabular}{|l|c|c|c|}
\hline Element & $\begin{array}{c}\text { Experimental } \\
\text { values }\end{array}$ & Certified values & Recovery (\%) \\
\hline $\mathrm{Cd}$ & $0.23 \pm 0.01$ & $0.26 \pm 0.01$ & 90.80 \\
\hline $\mathrm{Cu}$ & $31 \pm 3.10$ & $30 \pm 6.00$ & 101.60 \\
\hline $\mathrm{Cr}$ & $114 \pm 7.20$ & $104 \pm 9.00$ & 108.00 \\
\hline $\mathrm{Fe}$ & $67.10 \pm 2.58$ & $67.40 \pm 1.63$ & 99.24 \\
\hline $\mathrm{Mn}$ & $3.45 \pm 130$ & $3.41 \pm 160.00$ & 104.40 \\
\hline $\mathrm{Pb}$ & $35.89 \pm 1.85$ & $37.70 \pm 7.40$ & 95.00 \\
\hline $\mathrm{Zn}$ & $230.10 \pm 10.50$ & $223 \pm 10.00$ & 101.80 \\
\hline
\end{tabular}


(Table 1). $50 \mathrm{~mL}$ of each water sample was acidified by adding $1.5 \mathrm{~mL}$ nitric acid before metal analysis.

The bioconcentration factor (BCF) was calculated after metal concentrations were determined for water, sediment and fish muscle tissue. The BCF was defined in this study as the concentration of a metal in a fish tissue in relation to the concentration of that metal in the water and sediment surrounding that tissue. The BCF in this study was calculated using the Giesy and Wiener (1979) formula:

Bioconcentration $=\frac{\text { Concentration of metals }}{\text { Concentration of metal }}{ }_{\text {Environment }(\mathrm{ppb})}$

BCF values greater than 1000 were considered high and those below 250 low, while those between these extremes were considered as moderate (Nhiwatiwa et al., 2011). The $\mathrm{BCF}$ is a number that represents how much of a metal is in a tissue relative to how much of that metal is found in the aquatic environment; it is neither bioaccumulation nor biomagnification. Bioconcentration is important because metal ions usually occur in low concentrations in the aquatic environment and subtle physiological effects go unnoticed until gross chronic reactions become apparent (Wepener et al., 2001). However, this approach might lead to underestimation of BCFs for some elements due to high concentrations in other organs, such as for instance liver and kidney $(\mathrm{Cd})$ or bones $(\mathrm{Pb})$.

\section{Statistical analysis}

The data were analysed using Statistical Package for Social Scientists (SPSS) version 16.0. Statistically significant differences between sites and the reference site were determined by analysis of variance (ANOVA) for water physicochemical parameters to ascertain the differences from site to site. A $t$-test was performed for enzyme activity data to show differences between tissues as well as sites and exposure period. Significance differences $(p<0.05)$ were reanalysed by the Least Significant Difference (LSD) method to determine which of the sites were significantly different from the control. All parameters were expressed as mean \pm standard error. Paired sample $t$-test and Kruskall-Wallis ANOVA were used to test for differences in the biomarker responses between sites and exposures and metal concentrations in water. Spearman correlation tests were used to investigate the relationship between biomarker levels and metal concentrations in O. niloticus muscle tissue and sediments because sediments constitute the main reservoir for metals in aquatic environments (Villares et al., 2005).

\section{RESULTS}

\section{Physicochemical parameters}

The water in the Yellow Jacket River at Sites 2 and 3 appeared yellowish-brown due to a mixture of ochre and sediment, while the water at Site 1 appeared clear. The water in Mazoe River at Sites 5 and 6 appeared brownish-green due to sediment and algae. The physiochemical parameters measured did not vary significantly throughout the sampling period. Physicochemical parameters that were measured in situ at the 6 sampling sites and the control are given in Table 1 . Sites 2 and 3 generally showed high water temperature and electrical conductivity but low $\mathrm{pH}$ and dissolved oxygen.

The mean temperature of the water at Site 1 was comparable to the control and was significantly lower $(p<0.05)$ than the mean water temperature at Sites 2, 3, 4, 5 and 6. The mean $\mathrm{pH}$ of the water at the control site was not significantly different $(p>0.05)$ from that at Site 1 although it was significantly higher $(p<0.05)$ than at Sites 2, 3 and 4 . The electrical conductivity of the water at Sites 1, 4, 5, 6 and control was significantly lower $(p<0.05)$ than at Sites 2 and 3. The average amount of dissolved oxygen was lowest $(p<0.05)$ at Site $3(3.98)$ followed by Site 2 (4.52), and highest $(p<0.05)$ in the control (dissolved oxygen value of $7.20 \mathrm{mg} / \mathrm{L})$.

TABLE 2

Water physicochemical parameters measured in situ at the 6 sites and the control during the 6-week sampling period

\begin{tabular}{|l|c|l|c|c|}
\hline Site & $\begin{array}{c}\text { Temperature } \\
\left({ }^{\circ} \mathbf{C}\right)\end{array}$ & $\mathbf{p H}$ & $\begin{array}{c}\text { Conductivity } \\
(\boldsymbol{\mu S} / \mathbf{c m})\end{array}$ & $\begin{array}{c}\text { Dissolved oxygen } \\
(\mathbf{m g} / \mathbf{L})\end{array}$ \\
\hline $\mathbf{1}$ & $22.90^{\mathrm{a}}$ & $7.70^{\mathrm{a}}$ & $310.50^{\mathrm{a}}$ & $5.00^{\mathrm{a}}$ \\
\hline $\mathbf{2}$ & $26.10^{\mathrm{b}}$ & $5.00^{\mathrm{b}}$ & $696.60^{\mathrm{b}}$ & $4.50^{\mathrm{bc}}$ \\
\hline $\mathbf{3}$ & $25.30^{\mathrm{bc}}$ & $5.50^{\mathrm{c}}$ & $677.10^{\mathrm{c}}$ & $3.90^{\mathrm{b}}$ \\
\hline $\mathbf{4}$ & $24.90^{\mathrm{c}}$ & $6.90^{\mathrm{cd}}$ & $346.30^{\mathrm{a}}$ & $4.80^{\mathrm{ac}}$ \\
\hline $\mathbf{5}$ & $25.10^{\mathrm{bc}}$ & $7.60^{\mathrm{a}}$ & $366.90^{\mathrm{a}}$ & $4.70^{\mathrm{c}}$ \\
\hline $\mathbf{6}$ & $24.90^{\mathrm{c}}$ & $7.60^{\mathrm{a}}$ & $406.80^{\mathrm{a}}$ & $4.90^{\mathrm{c}}$ \\
\hline Control & $22.50^{\mathrm{a}}$ & $7.60^{\mathrm{a}}$ & $309.50^{\mathrm{a}}$ & $7.20^{\mathrm{d}}$ \\
\hline
\end{tabular}

Columns with different letters are significantly different $(p<0.05)$

TABLE 3

Average concentrations of selected metals in water at sampling sites $(\mu \mathrm{g} / \mathrm{L})$

\begin{tabular}{|l|c|c|c|c|c|c|c|}
\hline \multirow{2}{*}{ Metals } & \multicolumn{7}{|c|}{ Sampling sites } \\
\cline { 2 - 8 } & $\mathbf{1}$ & $\mathbf{2}$ & $\mathbf{3}$ & $\mathbf{4}$ & $\mathbf{5}$ & $\mathbf{6}$ & $\begin{array}{c}\text { Control water } \\
\text { in the lab }\end{array}$ \\
\hline $\mathrm{Cd}$ & $0.05 \mathrm{a}$ & $3.65^{\mathrm{c}}$ & $0.52^{\mathrm{b}}$ & $0.02^{\mathrm{a}}$ & $0.02^{\mathrm{a}}$ & $0.08^{\mathrm{a}}$ & 0.01 \\
\hline $\mathrm{Co}$ & $1.13 \mathrm{~b}$ & $177.50^{\mathrm{c}}$ & $126.60^{\mathrm{c}}$ & $7.39^{\mathrm{c}}$ & $0.78^{\mathrm{a}}$ & $0.59^{\mathrm{a}}$ & 0.02 \\
\hline $\mathrm{Cu}$ & $2.44 \mathrm{ab}$ & $29.85^{\mathrm{d}}$ & $7.70^{\mathrm{c}}$ & $2.06^{\mathrm{ab}}$ & $1.74^{\mathrm{a}}$ & $1.80^{\mathrm{a}}$ & 0.20 \\
\hline $\mathrm{Fe}$ & $489.20 \mathrm{~b}$ & $15960.60^{\mathrm{d}}$ & $2373.00^{\mathrm{c}}$ & $102.60^{\mathrm{a}}$ & $23.40^{\mathrm{a}}$ & $59.30^{\mathrm{a}}$ & 0.76 \\
\hline $\mathrm{Mn}$ & $45.70 \mathrm{ab}$ & $1147.40^{\mathrm{c}}$ & $1082.80^{\mathrm{c}}$ & $63.40^{\mathrm{b}}$ & $3.77^{\mathrm{a}}$ & $1.86^{\mathrm{a}}$ & 0.07 \\
\hline $\mathrm{Ni}$ & $2.66 \mathrm{a}$ & $158.40^{\mathrm{d}}$ & $105.60^{\mathrm{c}}$ & $7.36^{\mathrm{b}}$ & $2.63^{\mathrm{a}}$ & $1.39^{\mathrm{a}}$ & 0.19 \\
\hline $\mathrm{Pb}$ & 0.04 & $2.15^{\mathrm{b}}$ & $1.02^{\mathrm{a}}$ & 0.02 & $0.49^{\mathrm{a}}$ & $3.43^{\mathrm{c}}$ & 0.13 \\
\hline As & $12.66 \mathrm{c}$ & $7.59^{\mathrm{b}}$ & $5.25^{\mathrm{b}}$ & $2.75^{\mathrm{a}}$ & $2.34^{\mathrm{a}}$ & $2.27^{\mathrm{a}}$ & 0.10 \\
\hline Zn & $26.50 \mathrm{a}$ & $390.00^{\mathrm{c}}$ & $144.70^{\mathrm{c}}$ & $22.80^{\mathrm{a}}$ & $51.80^{\mathrm{b}}$ & $22.40^{\mathrm{a}}$ & 0.10 \\
\hline Nitrates $(\mathrm{mg} / \mathrm{L})$ & 0.50 & $2.50^{\mathrm{a}}$ & $2.70^{\mathrm{a}}$ & $11.00^{\mathrm{b}}$ & $12.00^{\mathrm{b}}$ & $14.00^{\mathrm{bc}}$ & 0.40 \\
\hline Phosphates $(\mathrm{mg} / \mathrm{L})$ & 0.10 & $0.25^{\mathrm{a}}$ & $0.20^{\mathrm{a}}$ & $2.10^{\mathrm{b}}$ & $3.90^{\mathrm{c}}$ & $4.00^{\mathrm{c}}$ & 0.10 \\
\hline
\end{tabular}

Rows with different letters are significantly different $(p<0.05)$ 
The mean concentrations of selected metals in water and sediment at the sampling sites are shown in Tables 2 and 3, respectively.

\section{Enzyme activities}

GST activity was not significantly different between the liver, gills and muscle at all sites including the controls. GST activity in all three tissues was lowest in control fish $(p<0.05)$, after both 4 - and 6-week exposure periods. Activity between the two exposure durations was not significantly different. There were no results at Site 2 below IDM after 4 weeks and 6 weeks and at Site 3 after 6 weeks due to fish mortality for all the measured biomarkers. The low levels of oxygen, low $\mathrm{pH}$ and high metal concentrations resulted in the lowest water quality and led to fish mortalities at sites closest to IDM.

Catalase activity was highest in the liver $(p<0.05)$ compared to the gills and muscle at all the sites after 4 weeks as well as after 6 weeks. It was also significantly higher in the gills $(p<0.05)$ than in the muscle. Catalase activity in all three tissues was lowest in the control fish $(p<0.05)$ after both exposure durations.

Pellet formation only took place in the liver and gill samples; hence MT was quantified in these tissues only. MT concentration was highest in the liver at Site 3 after 4 weeks and lowest in the control. There were no significant differences in the MT concentration in the liver and gills for both exposure durations (Fig. 4).
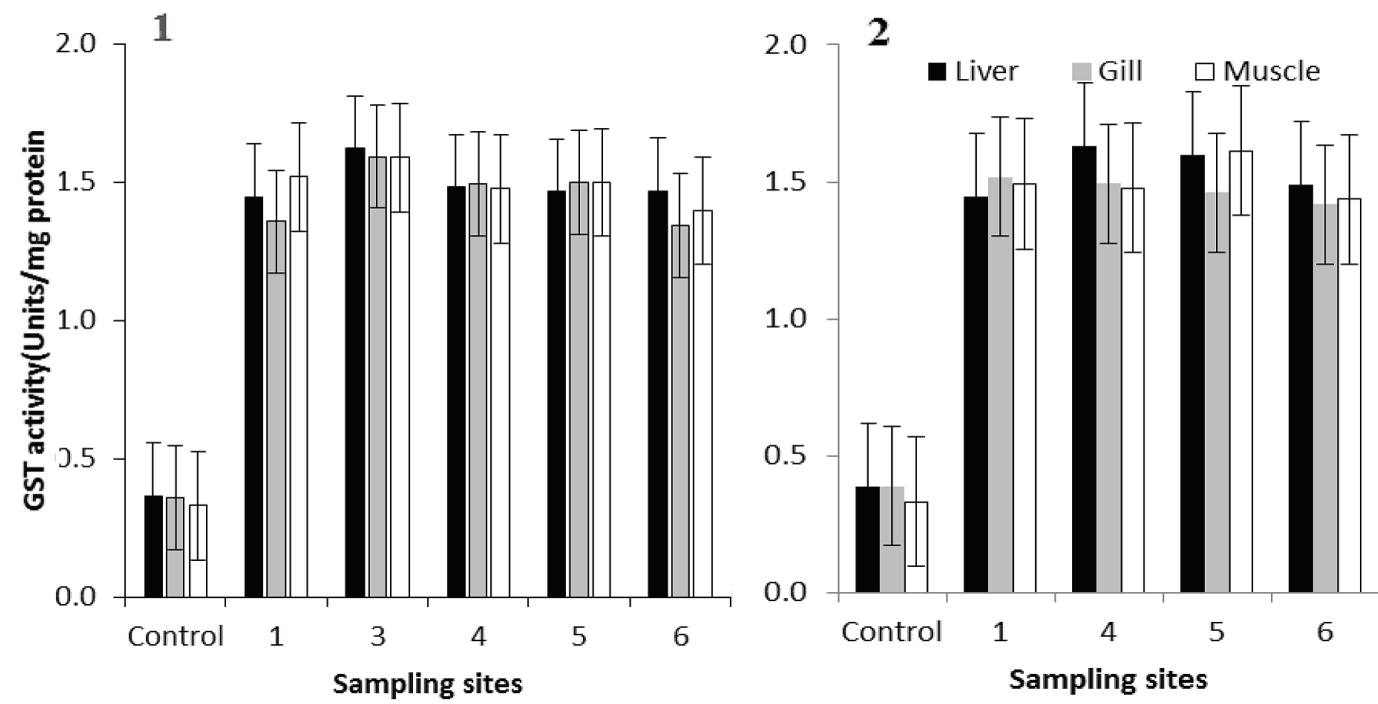

Figure 2

Glutathione S-transferase (GST) activity in the liver, gill and muscle at the 6 sites and control after 4 weeks (1) and 6 weeks (2). Error bars represent standard error of the mean.
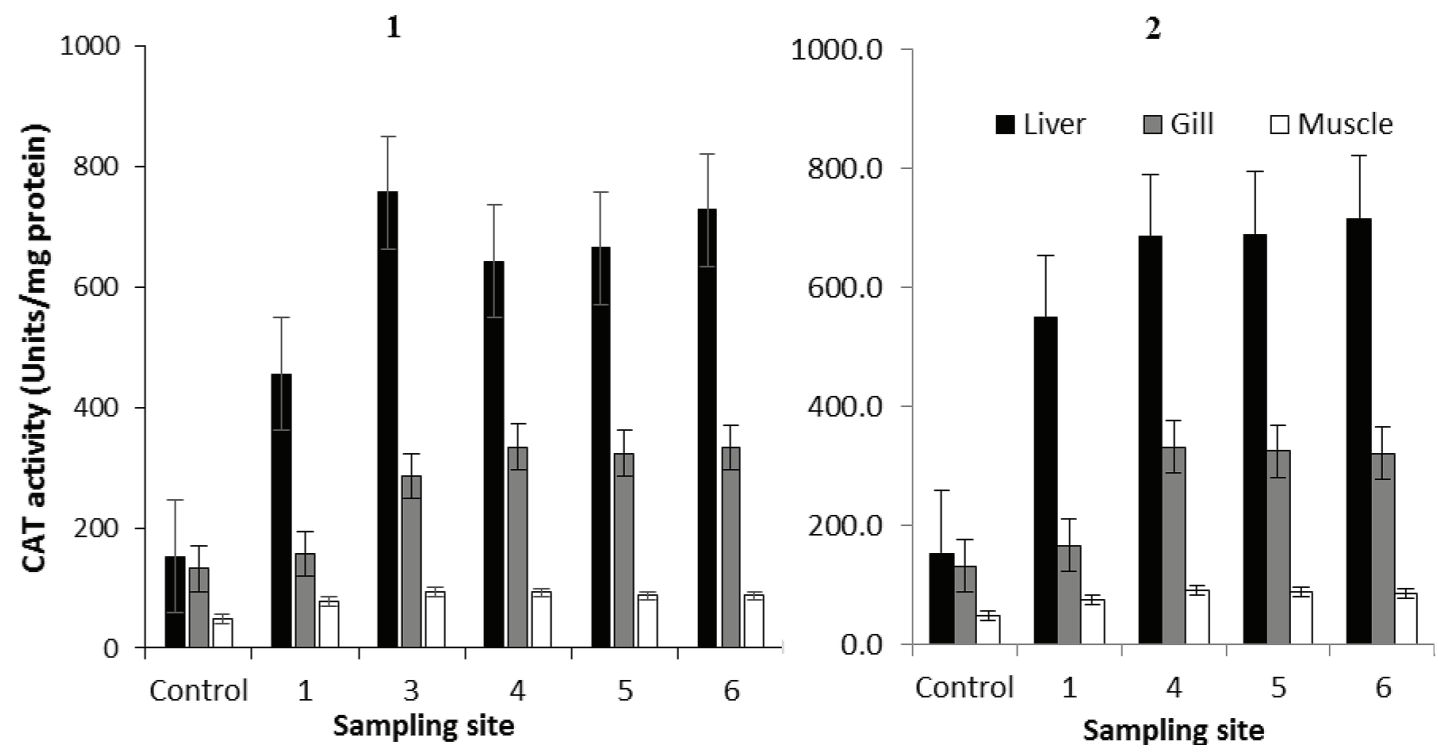

Figure 3

Catalase activity in the liver, gills and muscle after 4 weeks (Time 1) and 6 weeks (Time 2). Error bars represent standard error of mean ( $m \pm S E$ ). 

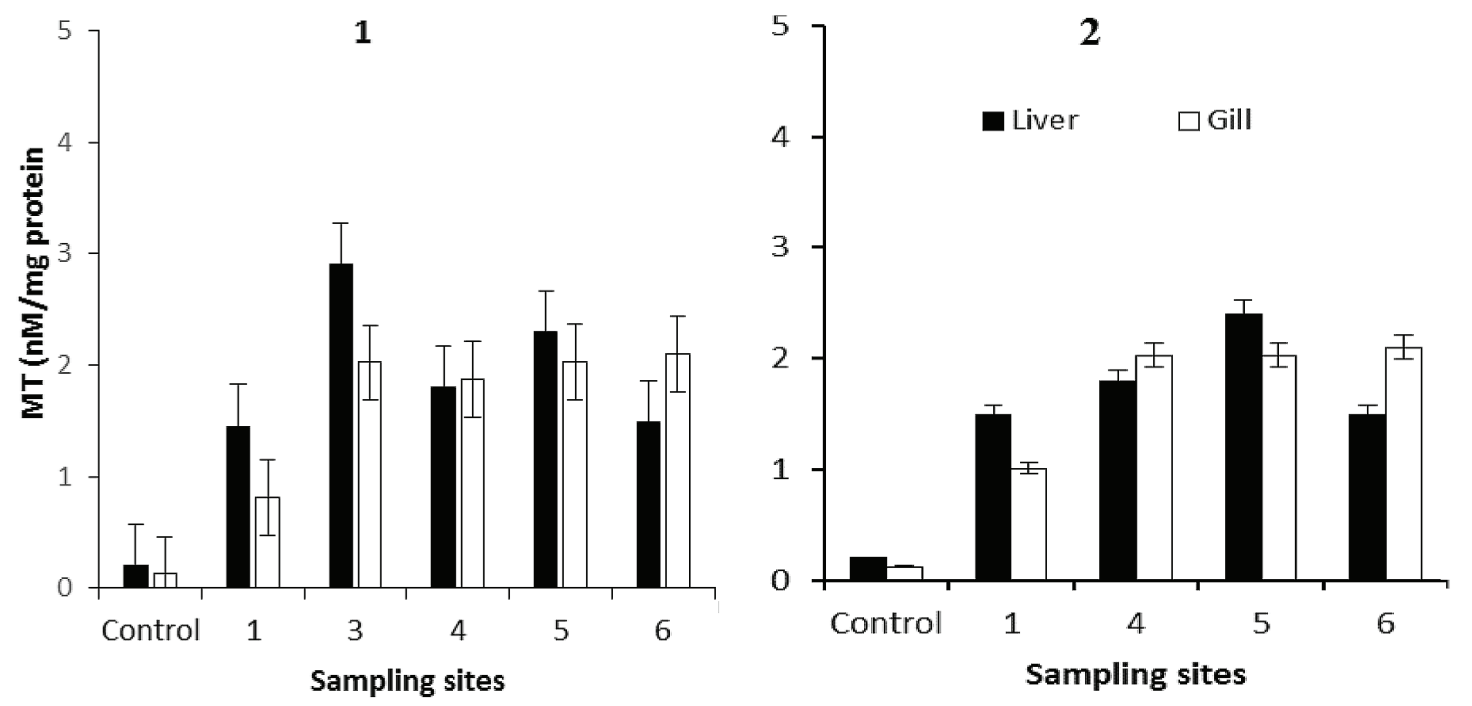

Figure 4

MT concentration in the liver and gills after 4 weeks (1) and 6 weeks (2). Error bars represent standard error of mean ( $m \pm S E$ )

\section{Metals}

The concentrations of cobalt, cadmium, copper, iron, nickel, zinc and lead in flowing water were significantly higher $(p<0.05)$ at Sites 2 and 3 while arsenic was highest at Site 1, decreasing downstream. The concentration of nitrates and phosphates were significantly higher $(p<0.05)$ at Sites 4,5 and 6 compared to the rest of the sites. The order of the concentrations of the metals was $\mathrm{Fe}>\mathrm{Mn}>\mathrm{Zn}>\mathrm{Cu}>\mathrm{Ni}>\mathrm{As}$ for Sites 1, 2, 3 and 4.

The concentrations of cobalt, iron, copper and zinc in sediments were significantly higher $(p<0.05)$ at Sites $2,3,4$ and 5 compared to Site 1, while Site 1 was comparable to Site 6 for arsenic and cobalt. Site 1 had the highest concentration of lead while Sites 4 and 5 had the highest concentration of manganese. The order of the concentrations of metals in the sediments were $\mathrm{Fe}>\mathrm{As}>\mathrm{Pb}>\mathrm{Mn}>\mathrm{Zn}>\mathrm{Cu}>\mathrm{Co}$.

The order of concentration of metals in O. niloticus was $\mathrm{Zn}>\mathrm{Fe}>\mathrm{Cu}>\mathrm{Ni}>\mathrm{As}>\mathrm{Mn}$ for all the sites. Cadmium was below detectable limit for O niloticus exposed at Sites 5 and 6 (Table 5).

\begin{tabular}{|c|c|c|c|c|}
\hline \multicolumn{5}{|c|}{ 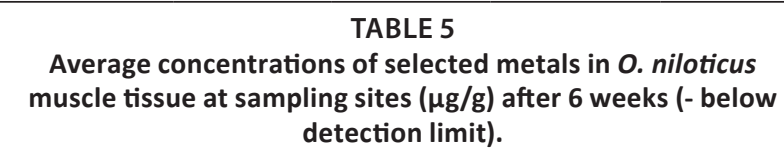 } \\
\hline \multirow{2}{*}{ Metals } & \multicolumn{4}{|c|}{ Sampling sites } \\
\hline & 1 & 4 & 5 & 6 \\
\hline $\mathrm{Cd}$ & 0.04 & 0.01 & - & - \\
\hline Co & 1.16 & 1.53 & 1.27 & 1.19 \\
\hline $\mathrm{Cu}$ & 12.14 & 13.83 & 12.45 & 13.04 \\
\hline $\mathrm{Fe}$ & 211.24 & 243.30 & 180.80 & 150.04 \\
\hline $\mathrm{Mn}$ & 2.64 & 1.64 & 1.48 & 1.43 \\
\hline $\mathrm{Ni}$ & 7.49 & 7.59 & 1.82 & 1.90 \\
\hline $\mathrm{Pb}$ & 0.45 & 0.34 & 0.37 & 0.38 \\
\hline As & 4.00 & 3.84 & 4.13 & 3.64 \\
\hline $\mathrm{Zn}$ & 491.80 & 520.70 & 519.70 & 428.50 \\
\hline
\end{tabular}

\begin{tabular}{|l|c|c|c|c|c|c|}
\hline \multicolumn{7}{|c|}{ TABLE 4 } \\
\hline \multirow{2}{*}{ Metals } & \multicolumn{7}{c|}{ Sampling sites } \\
\cline { 2 - 8 } & $\mathbf{1}$ & $\mathbf{2}$ & $\mathbf{3}$ & $\mathbf{4}$ & $\mathbf{5}$ & $\mathbf{6}$ \\
\hline $\mathrm{Cd}$ & 0.17 & 0.20 & 0.29 & 0.24 & 0.17 & 0.45 \\
\hline $\mathrm{Co}$ & 10.30 & 12.40 & 22.60 & 34.20 & 30.70 & 12.10 \\
\hline $\mathrm{Cu}$ & 14.60 & 29.10 & 51.80 & 34.90 & 30.90 & 44.90 \\
\hline $\mathrm{Fe}$ & 34.6390 & 251507.10 & 57000.50 & 61515.90 & 133862.40 & 63179.50 \\
\hline $\mathrm{Mn}$ & 102.00 & 80.20 & 75.30 & 191.70 & 217.60 & 39.60 \\
\hline $\mathrm{Ni}$ & 22.50 & 23.90 & 78.70 & 59.10 & 50.30 & 51.00 \\
\hline $\mathrm{Pb}$ & 197.40 & 178.00 & 38.80 & 20.70 & 26.30 & 40.40 \\
\hline $\mathrm{As}$ & 112.10 & 3804.00 & 264.60 & 121.00 & 76.20 & 115.70 \\
\hline $\mathrm{Zn}$ & 21.80 & 47.10 & 44.40 & 58.20 & 115.70 & 52.50 \\
\hline
\end{tabular}


TABLE 6

Bioconcentration factors comparing selected metals in water and sediment with $O$. niloticus muscle tissue at sampling sites after 6 weeks (- below detection limit).

\begin{tabular}{|c|c|c|c|c|c|c|c|c|}
\hline \multirow{3}{*}{ Metals } & \multicolumn{8}{|c|}{ Sampling sites } \\
\hline & 1 & 4 & 5 & 6 & 1 & 4 & 5 & 6 \\
\hline & \multicolumn{4}{|c|}{ Water } & \multicolumn{4}{|c|}{ Sediment } \\
\hline $\mathrm{Cd}$ & 0.80 & - & 0.24 & 0.04 & - & 0.5 & - & - \\
\hline Co & 1.03 & 2.02 & 0.11 & 0.04 & 0.04 & 0.21 & 1.63 & 2.02 \\
\hline $\mathrm{Cu}$ & 4.98 & 6.69 & 0.83 & 0.40 & 0.40 & 6.71 & 7.16 & 6.65 \\
\hline $\mathrm{Fe}$ & 0.43 & 2.53 & 0.006 & 0.004 & 0.001 & 2.37 & 7.73 & 2.53 \\
\hline $\mathrm{Mn}$ & 0.06 & 0.77 & 0.03 & 0.009 & 0.007 & 0.03 & 0.40 & 0.77 \\
\hline $\mathrm{Ni}$ & 2.82 & 1.37 & 0.33 & 0.13 & 0.04 & 1.03 & 0.69 & 1.37 \\
\hline $\mathrm{Pb}$ & 10.23 & 0.11 & 0.002 & 0.02 & 0.01 & 17.00 & 0.76 & 0.11 \\
\hline As & 0.32 & 1.60 & 0.04 & 0.03 & 0.05 & 1.40 & 1.82 & 1.60 \\
\hline $\mathrm{Zn}$ & 18.56 & 19.13 & 22.60 & 8.90 & 4.49 & 22.84 & 10.03 & 19.13 \\
\hline
\end{tabular}

Bioconcentration factors were in the low category for all the metals measured for both water and sediment. The highest BCF was observed for zinc (Table 6).

A strong positive correlation between $\mathrm{Ni}$ and Fe with MT at Sites 1 and 4 was observed. The PCA biplot (Fig. 5) describes $91.26 \%$ of the variation in the data where $70.16 \%$ is displayed on the first axis and $21.10 \%$ is displayed on the second axis.

\section{DISCUSSION}

The observed increased GST activity in the liver of O. niloticus at all sites compared to the reference shows its value as a biomarker of exposure. This is in agreement with other studies (Van de Oost et al., 2003; Farombi et al., 2007) where GST expression in fish liver as a biomarker of exposure to xenobiotics has been discussed. Increased GST activity has been demonstrated in liver tissue following exposure of the African Sharptooth Catfish (C. gariepinus) to a mixture of 170 -ethynylestradiol and benzopyrene (Perez-Lopez et al., 2002). GST activity has also been studied in freshly isolated hepatocytes of the Rainbow Trout (Oncorhynchus mykiss), in which elevated levels of the pi GST isoform were demonstrated (Perez-Lopez et al., 2002). The elevated GST activity suggests the presence of pollutants that induce oxidative stress in O. niloticus in Mazoe and Yellow Jacket Rivers. Muposhi et al. (2015) observed that GST biosynthesis in O. niloticus can be stimulated by a diverse range of xenobiotics in the aquatic environment. In a similar study, tilapia from polluted sites showed increased GST activity relative to tilapia from unpolluted sites (Mauserrat et al., 2007). Enhanced GST activity was also observed in cichlid fishes from polluted waters (Filho et al., 2001) and GST activity of fish caught from the polluted Bolgoda Dam was significantly higher than that of control fish (Panthiratne et al., 2008).

The high GST activity at Sites 5 and 6, which are not directly influenced by Iron Duke Mine, after both 4 and 6 weeks, could be a result of pollution of these sites by diffuse contaminants like agrochemicals from the surrounding farming community and illegal gold mining activities. A combination of agrochemicals such as fertilizers, herbicides and metals are known to modulate antioxidant defence systems, which can cause oxidative stress in aquatic organisms by reactive oxygen species (ROS) production

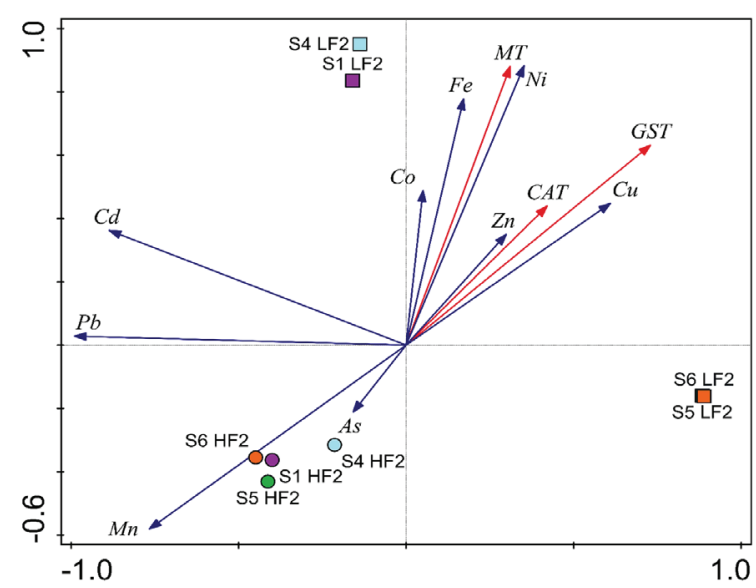

Figure 5

PCA biplot for the Yellow Jacket and Mazowe Rivers indicating differences in the biomarkers and selected metals at sampling sites

(Conners, 2002). Enhanced GST activity was observed in Canna panctalus exposed to the herbicide atrazine (Nwani et al., 2010). Siwela et al., (2009) also reported increased GST activity in C. gariepinus and O. mossambicus collected from the polluted Umguza Dam compared to organisms collected from the relatively pristine Wright Dam. During exposures to sublethal levels of organophosphate fertilizers, GST concentrations were substantially elevated in fish (Karakoc et al., 2007), most likely as a result of increased oxidative stress. The findings of this study support the observations of Gadagbui and James (2000) that GST activity in fish, especially in areas polluted by metals, pesticides and other industrial contaminants, appears to be the most sensitive and most widely used catalytic probe to observe and monitor pollution of aquatic ecosystems. It is also worth noting that the results of this study contradict other studies of GST activity as a biomarker in fish. During exposure to lethal levels of organophosphate pesticides, GST concentrations were found to be severely depleted in all organs of Cyprinidae fish living in Seyhan Lake, Turkey (Gul et al., 2004), and in Starlet (Aspensies ruthenus L.) from the Danude River, Serbia (Stanic et al., 2005). This was attributed to ATP depletion, 
synthetic enzyme destruction and the conversion of severely injured cells from a reduced to an oxidized state (Gul et al., 2004). Furthermore, Filho et al. (2001) observed that GST results should be interpreted with caution since the activity of the enzyme can be influenced by natural factors that can confound the results. Major differences in sensitivity to environmental contaminants have been shown to exist between species (Lacroix and Hontela, 2004).

The low levels of oxygen, low $\mathrm{pH}$ and high metal concentrations resulted in the lowest water quality and led to fish mortalities at sites closest to IDM. Impacts of low DO levels include an effect on the survival of fish by increasing their susceptibility to diseases and retardation of growth. It also causes impaired swimming ability, alteration in feeding and migration and, when extreme, leads to rapid death (Bobmanuel et al., 2006). A combination of low $\mathrm{pH}$ and the high concentration of dissolved metals as well as the synergistic effects of associated changes in other physicochemical parameters of the water could have caused the fish mortality. A study of the distribution of fish in Pennsylvania streams affected by AMD found fish to be severely impacted at $\mathrm{pH} 4.5-5.5$. These researchers also found complete loss of fish in $90 \%$ of stream waters of $\mathrm{pH} 4.5$. Low $\mathrm{pH}$ can be directly toxic and fatal to fish by causing damage to fish gills, while dissolved metals mobilized by these acidic conditions are extremely toxic (Ravengai et al., 2005; Mapanda et al., 2007). In a similar study, Mlambo (2003) could not get results for enzymes of oxidative stress at some sites because of fish mortality. The significantly higher cadmium concentrations at Sites 2 and 3 can also explain fish mortality at these sites. Species more sensitive to cadmium may be more susceptible to adrenal impairment and exhaustion of cortisol secretion contributing to compromised survival capacity in chronic metalcontaminated environments (Lacroix and Hontella, 2004).

The observed higher CAT activity in the liver, followed by the gills, is in agreement with Velkova et al. (2008), who observed that CAT activity varies greatly in tissues and is highest in the liver and kidney and lowest in connective tissue. This is probably because the liver is genetically programmed to be the metabolic regulator, is highly oxidative tissue and may concentrate xenobiotics. Tilapia from polluted sites showed a significantly higher CAT activity than tilapia from unpolluted sites (Behl, 2006). Increased CAT activity is usually observed in the face of environmental xenobiotics since it is part of the SOD-CAT system, which is the first line of defence against oxidative stress (Farombi et al., 2007).

Increased acidity observed at Sites 2 and 3 resulted in the bioavailability of some metals, which caused toxic effects overwhelming the antioxidant defences (Farombi et al., 2007). Once acid mine drainage is created, metals are released into the surrounding environment and become readily available to aquatic organisms. When fish are exposed to metals and $\mathrm{H}^{+}$ ions through their gills, impaired respiration may result from chronic and acute toxicity. Low $\mathrm{pH}$ alters gill membranes or changes gill mucus resulting in death due to hypoxia (Conners, 2002). The observed elevated levels of $\mathrm{Fe}, \mathrm{As}, \mathrm{Pb}, \mathrm{Mn}$ and $\mathrm{Cu}$ in the water and sediments (Table 2 and 3) at Sites 2 and 3, which are directly influenced by Iron Duke Mine, supports the claim that acid mine drainage poses a threat to native aquatic life (William and Smith, 2000) through elevated acidity and the accumulation of metals. Site 1 which has been regarded as the reference site in previous studies, below the Manyuchi Dam, which acts as a sink for pollutants, showed increased enzyme activity. There are no known anthropogenic impacts described in the literature for this site. The elevated metals and, in turn, increased biomarker activity may be a result of the influence of the underlying geology of the banded ironstones of the Great Dyke, which the river cuts through. This is in agreement with Javed and Usmani (2014), who found that where no human impacts are present, the elevated levels of metals are probably caused by natural geological weathering.

Catalase is known to provide the first line of defence against ROS. Some pollutants like copper and iron are well-known for their ability to redox cycle via interacting with hydrogen peroxide and catalysing Haber-Weiss and Fenton-like reactions that produce highly toxic hydroxyl radicals (Karakoc et al., 2007). Velkova et al. (2008) observed that cadmium may also cause cytotoxicity by reacting with $\mathrm{H}_{2} \mathrm{O}_{2}$ to produce hydroxyl radicals. Elevated levels of CAT were observed in Mytilus galloprovincialis exposed to polluted water from the Adriani Sea (Bochetti and Rigoli, 2006) and in Canna panctatus exposed to pesticides (Nwani et al., 2010). Catalase activity was also shown to be elevated in mussels exposed to the insecticide cypermethrine (Kenan et al., 2010), and in freshwater snails Lymnaea natalensis exposed to polluted dam water (Siwela et al., 2010).

Cd constitutes a major environmental health problem because it increases oxidative stress, mainly causing renal injury, which leads to renal dysfunction, and it has been demonstrated to be the major inducer of MTs in molluscs (Géret et al., 2002) and O. niloticus exposed to different concentrations of metals (Alti and Canli, 2008). The increased expression of MTs at Sites 1, 4, 5 and 6 after 4 weeks corresponds with elevated levels of the measured metals in water and sediments, and accumulation in fish at these sites. Metallothionein levels were shown to increase in the liver only of cadmium-exposed O. niloticus, indicating that the liver is a suitable tissue to determine response of MTs to metal exposure in environmental monitoring studies (Atli and Canli, 2008).

Significant relationships between antioxidant activity and lead, copper, cadmium and zinc were observed in O. niloticus from Pote River (Muposhi et al., 2015). In this study, zinc was observed to have the highest bioconcentration factor at Sites 1, 4 and 5, corresponding with accumulated levels in fish, and could be the main metal responsible for increased antioxidant activity (Fig. 5). Increased concentration of zinc in fish is in agreement with Crafford and Avenant-Oldewage (2011), who observed elevated zinc levels in the skin of catfish from the Vaal River system. Zinc is an essential element present in numerous enzymes and plays a role in binding carbon dioxide and water in teleost fish forming carbonic acid (Crafford and Avenant-Oldewage, 2011). Its toxic action in Tilapia sparrmanii exposed to a copper, iron and zinc mixture was observed to be primarily limited to the liver (Wepener et al., 2001), which is in agreement with increased antioxidant activity in the liver observed in this study.

\section{CONCLUSIONS}

The timing of the sampling period appears to have no significant relationship with the activities of the oxidative stress biomarkers observed in this study. The increased activities of GST, CAT and MT in the Yellow Jacket and Mazoe Rivers led us to conclude that $O$. niloticus can be used successfully as a bio-indicator. These oxidative stress biomarkers were shown to be useful in assessing pollution from point sources such as acid mine drainage and diffuse sources such as commercial agriculture. The biomarker responses indicate that there is a physiological attempt by $O$. niloticus to deal with and 
mitigate the negative impacts the pollutants may induce by stimulating antioxidant protective mechanisms. The state of the water quality of the two rivers was shown to be impaired by the increased activities of the oxidative stress biomarkers. The high bioconcentration factors for zinc, copper and lead in $O$. niloticus relative to the water suggests that there is potential to use metal concentrations in fish muscle as indicators of metal contamination in aquatic ecosystems.

\section{ACKNOWLEDGEMENTS}

We gratefully acknowledge the Zimbabwe Ministry of Higher and Tertiary Education Science and Technology Development, University of Johannesburg, Organisation for Women in Science for the Developing World (OWSD) and the Swedish International Development Cooperation Agency (SIDA) for funding. Views expressed are those of the authors not the funding entities.

\section{REFERENCES}

ADAMS SM, GIESY JP, TREMBLAY LA and EOSON CT (2001) The use of biomarkers in Ecological Risk Assessment: Recommendations from the Christchurch Conference on Ecotoxicology. Biomarkers 6 1-6. https://oi. org/10.1080/135475001452724

ALTI G and CANLI M (2008) Responses of metallothionein and reduced glutathione in a freshwater fish Oreochromis niloticus following metal exposures. Environ. Toxicol. Pharmacol. 25 33-38. https://doi.org/10.1016/j.etap.2007.08.007

BEHL R (2006) Stimulation of catalase activity in carp (Cyprinus carpio) ovarian follicles. Fish Physiol. Biochem. 32 203-207. https:// doi.org/10.1007/s10695-006-0012-7

BOBMANUEL NOK, GABRIEL UU and EKWEOZOR IKE (2006) Direct toxic assessment of treated fertilizer effluents to Oreochromis niloticus, Clarias garrepinus and Catfish hybrid (Heterobranchus bidorsalis (male) x Clarias graepinus (female). Afr. J. Biotechnol. 5 (8) 635-642.

BOCHETTI R and RIGOLI F (2006) Seasonal variability of oxidative stress biomakers, lysosomal parameters, metallothioneins and peroxisomal enzymes in the Mediterranian mussel Mytilus galloprovincialis from Adriani Sea. Chemosphere 65 913-921. https://doi.org/10.1016/j.chemosphere.2006.03.049

BRADFORD MM (1976) A rapid and sensitive method for the quantification of microgram quantities of protein utilizing the principle of protein-dye binding. Anal. Biochem. 72 248-254. https://doi.org/10.1016/0003-2697(76)90527-3

CHIZVONDO R (2007) An evaluation of the rehabilitated Iron Duke Mine Tailings - Environ Green site, Mazoe Zimbabwe. BSc dissertation, Land Conservation and Reclamation, Bindura University of Science Education, Zimbabwe.

COHEN H, DEMBIEC D, and MARAUS J (1970) Measurements of catalase activity in tissue extracts. Anal. Biochem. 34 30-38. https:// doi.org/10.1016/0003-2697(70)90083-7

CONNERS DE (2002) Biomarkers of oxidative stress in freshwater clams (Corbiala fluminea) as mechanistic tools to evaluate the impairment of the stream ecosystem health by lawn care pesticides. PhD dissertation, University of Georgia, Athens, Georgia.

CRAFFORD D and AVENANT-OLDEWAGE A (2011) Uptake of selected metals in tissues and organs of Clarias gariepinus (sharptooth catfish) from the Vaal River System -Chromium, copper, iron, manganese and zinc. Water SA 37 (2) 181-200. https:// doi.org/10.4314/wsa.v37i2.65864

FILHO D W, TORRESL MA, TRIBESSL TP, PEDRESOSA RC and SOARES CHL (2001) Influence of season and pollution on the antioxidant defenses in the cichlid fish Acara Geophagus brasiliensis. Braz. J. Med. Biol. Res. 34 719-726. https://doi. org/10.1590/S0100-879X2001000600004

FAROMBI EO, ADELAWO OA and AJIMOKO YR (2007) Biomarkers of oxidative stress and heavy metal levels as indicators of environmental pollution in African Cat Fish (Clarias gariepinus) from Nigeria Ogun River. Int. J. Environ. Resour. Public Health 4 158-165. https://doi.org/10.3390/ijerph2007040011

GADAGBUI K and JAMES MO (2000) Activities of glutathione S-transferase (GST) from channel catfish whole intestine. Aquat. Toxicol. 9 29-37.

GERBER R, SMIT NJ., VAN VUREN JHJ, NAKAYAMA SMM, YOHANNES YB, IKENAKA Y and WEPENER V (2015) Application of a Sediment Quality Index for the assessment and monitoring of metals and organochlorines in a premier conservation area. Environ. Sci. Pollut. Res. 22 (24) 19971-19989. https://doi.org/10.1007/s11356-015-5206-Z

GÉRET F, JOUAN A, TURPIN V, BEBIANNO MJ and COSSON RP (2002) Influence of metal exposure on metallothionein synthesis and lipid peroxidation in two bivalve mollusks: the oyster (Crassostrea gigas) and the mussel (Mytilus edulis). Aquat. Living Resour. 15 61-66. https://doi.org/10.1016/S0990-7440(01)01147-0

GIESY JN JP and WIENER JG (1979) Concentrations of Cd, Cu, Mn, $\mathrm{Pb}$, and $\mathrm{Zn}$ in fishes in a highly organic softwater pond. J. Fish. Res. Board Can. 51 (4) 290-310.

GUL S, BELGE-KURUTAS E, YILDIZ E, SAHAN A and DORAN F (2004) Pollution correlated modifications of liver antioxidant systems and histopathology in fish (Cyprinidae) living in Seyhan Dam Lake, Turkey. Environ. Toxicol. 30 605-609.

HABIG W H, PABST MJ and JAKOBY WB (1974) Glutathione $\mathrm{S}$ transferases. The first enzymatic step in mercapturic acid formation. J. Biol. Chem. 249 (22) 7130-7139.

JAVED M and USMANI N (2014) Impact of heavy metal toxicity on hematology and glycogen status of fish: A review. Proc. Natl Acad. Sci. India B: Biol. Sci. 85 (4) 889-900.

KARAKOC FT, HEWER A, PHILIPS DA, GAINES AF and YUREGIN G (2007) Biomarkers of marine pollution observed in species of mullet living in two eastern Mediterranean harbours. Biomarkers 45 234-241.

KENAN K, MISE TS and ENGIN S (2010) Effects of cypermethrin on antioxidant status, oxidative stress biomarkers behaviour and mortality in the fish water mussel Unio elongatulus eucirrus. Environ. Pollut. 133 275-281.

LACROIX A and HONTELLA A (2004) A comparative assessment of the adrenotoxic effects of cadmium in teleost species, rainbow trout, Oncorhynchus mykiss, and yellow perch, Perca flavescens. Aquat. Toxicol. 67 13-21. https://doi.org/10.1016/j. aquatox.2003.11.010

MAGADZA CHD and MASENDU H (1986) Some observations on effluent in the Yellow Stream, Zimbabwe. Zim. Sci. News 20 11-15.

MAPANDA F, NYAMADZAWO G, NYAMANGARA J and WUTA M (2007) Effects of discharging acid-mine drainage into evaporation ponds lined with clay on chemical quality of the surrounding soil and water. Phys. Chem. Earth 32 1376-1383. https://doi. org/10.1016/j.pce.2007.07.041

MAUSERRAT JM, MARTINEZ PE, GERACITANO LA, AMADO LL, MARTINS CM, PINHO GL, CHAVES IS, FERREIRA-CRAVO M, VENTURA-LIMA J and BIANCHINI A (2007) Pollution biomarkers in estuarine animals: A critical review and new perspectives. Comp. Biochem. Physiol. 146 221-234.

MLAMBO SS (2010) The effects of selected heavy metals and DDT exposure on selected aquatic organisms: a laboratory and field study. PhD thesis, University of Johannesburg, South Africa.

MHLANGA L, DAY J, CHIMBARI M, SIZIBA N and CRONBERG $G$ (2006) Observation on the limnological conditions associated with a fish kill of Oreochromis niloticus in Lake Chivero following a collapse of an algal bloom. Afr. J. Ecol. 44 199-204. https://doi. org/10.1111/j.1365-2028.2006.00625.x

MUISA N, HOKO Z and CHIFAMBA P (2010) Impacts of alum residue on water quality and fish: a case of Morton Jaffray Water Works, Zimbabwe. $11^{\text {th }}$ WaterNet/WARFSA/GWP-SA Symposium, 27-29 October 2010, Victoria Falls, Zimbabwe.

MUPOSHI VK, UTETE B, SITHOLE-NIANG I and MUKANGENYAMA S (2015) Active biomonitoring of a subtropical river using glutathione-S-transferase (GST) and heat shock proteins (HSP 70) in Oreochromis niloticus as surrogate biomarkers of metal contamination. Water SA 41 425-431. https:// doi.org/10.4314/wsa.v41i3.15 
NHIWATIWA T, BARSON M, HARRISON AP, UTETE B and COOPER RG (2011) Metal concentrations in water, sediment and sharp tooth catfish Clarias gariepinus from three peri-urban rivers in the upper Manyame catchment, Zimbabwe. Afr. J. Aquat. Sci. 36 (3) 243-252. https://doi.org/10.2989/16085914.2011.636906

NYAMADZAWO G, MAPANDA F, NYAMANGARA J, WUTA M, NYAMUGAFATA P and GILLER KE (2007) Short term Impacts of sulphate mine dump rehabilitation on below ground water and surface waters of Yellow Jacket River, Mazowe, Zimbabwe. Phys. Chem. Earth 32 1376-1383. https://doi.org/10.1016/j.pce.2007.07.043

NWANI CD, LAKRA WS, NAGPURE NS, KUMMAR R, KUSHWANA NS and SRIVASTAVA SK (2010) Toxicity of the herbicide atrazine: Effects in lipid peroxidation and activities of antioxidant enzymes in the freshwater fish Canna panctatus (Bloch). Int. J. Environ. Resour. Public Health 7 2398-3312. https:// doi.org/10.3390/ijerph7083298

PANTHIRATNE A, CHANDRASEKERA LWHU and PANTHIRATNE KAS (2008) Use of biomarkers in Nile Tilapia (Oreochromis niloticus) to assess the impacts of pollution in Bolgoda Lake and urban waterbody in Sri Lanka. Environ. Monit. Assess. 156 361-375. https://doi.org/10.1007/s10661-008-0490-4

PEREZ-LOPEZ M, NOVOA-VALINAS MC and NLELGAR-RIOL MJ (2002) Glutathione S-transferase-erase cytosolic isoforms as biomarkers of polychlorinated biphenyl experimental contamination in rainbow trout. Toxicol. Lett. 136 97-106. https:// doi.org/10.1016/S0378-4274(02)00284-9

RAVENGAI S, LOVE D, LOVE I, GRATWICKE B, MANDINGAISA $O$ and OWEN RJS (2005) Impact of Iron Duke Pyrite Mine on water chemistry and aquatic life, Mazoe Valley, Zimbabwe. Water SA 31 (2) 219-228. https://doi.org/10.4314/wsa.v31i2.5190

SADC (2000) Revised Protocol on Shared Watercourses in the Southern African Development Community. Southern African Development Community.

SIWELA AH, NYATHI CB and NAIK YS (2009) Metal accumulation and antioxidant enzyme activity in $C$. gariepinus, catfish and $O$. mossambicus, tilapia, collected from lower Mguza and Wright Dams, Zimbabwe. Bull. Environ. Contam. Toxicol. 83 (5) 648-651. https://doi.org/10.1007/s00128-009-9861-y

SIWELA AH, NYATHI CB and NAIK YS (2010) A comparison of metal levels and antioxidant enzymes in water snails, Lymnaea natalensis exposed to sediment and water collected from Wright Dam and Lower Mguza Dam, Bulawayo, Zimbabwe. Bull. Environ. Contam. Toxicol. 89 342-351. https://doi.org/10.1016/j.ecoenv.2010.08.001

SLATINSKA T, SMATNA M, HAVELKOVA $M$ and SVOBODOVA Z (2008) Review article: biochemical markers of aquatic pollution in fish - glutathione S-transferase. Folia Vet. 52 129-134.

STANIC B, ANDRIC N, ZORIC S, GARUBOR-LAJSIC G and KOVACEVIC R (2005) Assessing Pollution in the Danube River near Nove Sad (Serbia) using several biomarkers in starlet (Acipenser ruthenus L). Ecotoxicol. Environ. Saf. 26 351-359.

TAZVIVINGA A, JIRI Z, MUYAMBO S, NYAMADZAWO G and GOTOSA J (2012) Passive biomonitoring of Mazowe and Yellow Jacket Rivers, Zimbabwe: Use of the South African Scoring System and Habitat Assessment Index. Glob. Adv. Res. J. Eng. Technol. Innovation 1 (8) 195-204.

TODD C and ROUX D (2000) Design of an aquatic biomonitoring programme using the South African Scoring System as a case study. $1^{\text {st }}$ WARFSA/WaterNet Symposium: Sustainable Use of Water Resources, Maputo, 1-2 November 2000.

VAN DER OOST R, BEYER J and VERMEULEN NP (2003)

Fish bioaccumulation and biomarkers in environmental risk assessment: A review. Environ. Toxicol. Pharmacol. 13 51-149. https://doi.org/10.1016/S1382-6689(02)00126-6

VELKOVA JL, KOSTOSK G and JORDANOSKA B (2008) Antioxidative enzymes in fish as biochemical indicators of aquatic pollution. Bulgarian J. Agric. Sci. 14 235-237.

VIARENGO A, BURLANDO B, DONDERO F, MARRO A and FABBRI R (1997) Metallothionein as a tool in biomonitoring programs. Biomarkers 4 455-466.

VILLARES R, CARRAL E, PUENTE XM and CARBALLEIRA A (2005) Metal concentrations in estuarine invertebrates in relation to sediments. Bull. Environ. Contam. Toxicol. 75 (3) 592-599. https://doi.org/10.1007/s00128-005-0792-y

WEPENER V, VAN DYK C, BERVOETS L, O'BRIEN G, COVACI A and CLOETE Y (2011) Assessment of the influence of multiple stressors on the Vaal River, South Africa. Phys. Chem. Earth 36 949-962. https://doi.org/10.1016/j.pce.2011.07.075

WEPENER V, VAN VUREN JHJ, CHATIZA FP, MBIZI Z, SLABBERT L and MASOLA B (2005) Active biomonitoring in fresh water environments: early warning signals from biomarkers in assessing biological effects of diffuse sources of pollutants. Phys. Chem. Earth 30 751-761. https://doi.org/10.1016/j.pce.2005.08.018

WEPENER V, VAN VUREN JHJ and DU PREEZ HH (2001) Uptake and distribution of a copper, iron and zinc mixture in gill, liver and plasma of a freshwater teleost, Tilapia sparrmanii. Water SA 27 (1) 99-108.

WILLIAMS TM and SMITH B (2000) Hydrochemical characterization of acute acid mine drainage at Iron Duke Mine, Mazoe, Zimbabwe. Environ. Geol. 39 272-278. https://doi.org/10.1007/s002540050006 